\title{
KEPERCAYAAN MASYARAKAT BANJAR TERHADAP BULAN SAFAR: Sebuah Tinjauan Psikologis
}

\author{
Siti Faridah* dan Mubarak**
}

\begin{abstract}
Bulan Safar adalah salah satu bulan dalam Kalender Hijriyah, Bulan Safar sebenarnya bulan biasa. Tidak terdapat keistemewaan atau kesialan di bulan itu. Kepercayaan akan adanya kesialan di bulan Safar sudah ada pada bangsa Arab sejak raman Jabiliyah. Faktor yang mendasari sebagian masyarakat Banjar mempercayai dan melaksanakan amaliah tertentu di bulan Safar berdasarkan keterangan dari kitab-kitab ulama terdabulu yang disampaikan oleh para tokoh agama sehingga terjadi proses sugesti dan peniruan perilaku (modelling). Tradisi tersebut diwariskan turun temurun bingga sekarang. Motivasi dan tujuannya adalah untuk memperoleb keselamatan dan menbindari kesialan.
\end{abstract}

Kata kunci: kepercayaan, masyarakat Banjar, tradisi, psikologis.

\section{Pendahuluan}

Sebelum Islam masuk ke Indonesia, penduduk Indonesia sudah memeluk agama Hindu, Budha dan kepercayaan primitif (animisme dan dinamisme). Setelah datangnya Islam, kepercayaan lama yang mereka yakini kadang-kadang masih ada dalam pikiran dan tetap dilaksanakan dalam kehidupan sehari-hari. ${ }^{1}$

Kepercayaan adalah suatu penerapan yang bersifat kongkrit dari nilai yang dimiliki. ${ }^{2}$ Kepercayaan yang dilaksanakan oleh suatu masyarakat biasanya diwariskan secara turun menurun kepada anak cucu mereka sebagai tradisi.

Bangsa Indonesia dikenal sebagai bangsa yang religius, yang kehidupan masyarakatnya kental dengan aktivitas dan semangat keagamaan. Hal inipun terlihat pada masyarakat Banjar di Kalimantan Selatan. Orang Banjar adalah pemeluk Islam sehingga agama Islam boleh dikatakan sudah merupakan ciri

\footnotetext{
${ }^{1}$ Hilman Hadi Kusumah, Antropologi Agama, (Bandung: Citra Aditya Bakti, 1993), h.103.

${ }^{2}$ Amin Abdullah, Agama dan Akal Pikiran, (Jakarta: Rajawali, 1989), h. 122.

${ }^{3}$ Alfani Daud, Islam dan Masyarakat Banjar, Diskeripsi dan Analisi Kebudayaan Banjar, I (Jakarta: RajaGrafindo Persada, 1997), cet. Ke-1, h.47-48. Lihat juga: Uriansyah, et. all. (editor), Urang Banjar dan Kebudayaannya, (Banjarmasin: Badan Penelitian dan Pengembangan Daerah propinsi Kalimantan Selatan, 2005), h. 187
} 
keagamaan mereka. Dengan kata lain orang Banjar identik dengan Islam. Menurut Alfani Daud, sejak abad ke-18, Islam sudah menjadi identitas orang Banjar. $^{3}$

Secara teologis, suatu kegiatan keagamaan tidak mustahil akan bergeser dari kemurniannya bila bercampur dengan tradisi, karena terkesan sebagai kepercayaan bahkan keyakinan. Menurut Robenson Smith "suatu upacara bisa tetap, walau berlatar belakang keyakinan, namun maksud dan Doktrinnya berubah-ubah. ${ }^{4}$

Sesuai dengan kondisi keagamaan masyarakat Banjar, maka corak kehidupan masyarakat sehari-hari banyak dijiwai atau diwarnai oleh ajaran Islam. Jadi tradisi atau adat istiadat yang dilakukan secara turun temurun mungkin saja diwarnai agama Islam, namun tidak mustahil juga ada unsurunsur non Islam, seperti kepercayaan terhadap bulan Safar yang dipercaya sebagian masyarakat Banjar sebagai bulan pembawa sial.

Secara historis, kepercayaan terhadap bulan Safar telah ada di kalangan masyarakat Arab Jahiliyah sejak zaman dahulu. Disebutkan bahwa pada hari Rabu terakhir di bulan Safar diturunkan 320.000 (tiga ratus dua puluh ribu) bala. $^{5}$

Tidak semua masyarakat Banjar Kalimantan Selatan percaya terhadap kesialan bulan Safar, namun sebagian dari mereka mempercayai dan banyak di antara mereka yang melakukan tradisi atau adat istiadat yang berupa aktivitas tertentu. Intinya mereka sangat berhati-hati di bulan Safar. Kepercayaan dan tradisi itu masih ada dan dilestarikan oleh sebagian masyarakat Banjar terutama disebabkan oleh adanya ulama atau guru-guru agama yang menyampaikannya kepada jamaahnya. Faktor pendukung lainnya adalah karena faktor psikologis yang membuat sebagian masyarakat tetap dengan kepercayaan dan tradisinya.

Berdasarkan penjajakan awal dapat diketahui beberapa tradisi atau aktivitas yang dilaksanakan dan tidak dilaksanakan masyarakat Banjar di bulan Safar antara lain melakukan upacara tolak bala pada hari Arba Mustamir, melaksanakan batimbang anak yang lahir pada bulan Safar, tidak melaksanakan perkawinan dan tidak memulai usaha dagang.

Dari apa yang disebutkan di atas terlihat betapa kepercayaan masyarakat terhadap bulan Safar yang dianggap dapat membawa kesialan menimbulkan

${ }^{3}$ Koentjaraningrat, Sejarah Antropologi I, (Jakarta: Aksara Baru, 1982), h. 67.

${ }^{4}$ M. Qusairi Hamzah, Risalah Amaliah, (Pemangkih, 1998M/1419H), h. 230. 
upacara atau aktivitas yang harus mereka lakukan. Dari sini dapat pula diketahui bahwa orang berbuat atau tidak berbuat pasti ada motivasi dan tujuannya, paling tidak mereka takut atau khawatir terhadap bahaya yang mungkin ditimbulkannya.

Berdasarkan latar belakang masalah di atas, maka penelitian ini bertujuan untuk menjawab permasalahan, bagaimana gambaran kepercayaan dan tradisi sebagian masyarakat Banjar terhadap bulan Safar, faktor psikologis apa yang mendasari kepercayaan dan tradisi tersebut serta apa saja motivasi dan tujuan sebagian masyarakat Banjar melakukan tradisi yang berkaitan dengan bulan Safar tersebut.

Untuk menghindari kesalahpahaman terhadap penelitian ini, maka penulis merasa perlu untuk membuat definisi operasional sebagai berikut:

Kepercayaan berasal dari kata percaya yang artinya mengakui atau yakin bahwa sesuatu memang benar atau nyata, anggapan atau keyakinan bahwa sesuatu yang dianggap atau dipercayai itu benar-benar atau nyata, sesuatu atau nyata, sesuatu yang dipercaya. ${ }^{6}$ Kepercayaan yang dimaksud dalam penelitian ini adalah keyakinan yang merupakan rasa keagamaan dalam diri manusia terhadap sesuatu yang dipercayainya, yaitu kepercayaan terhadap bulan Safar.

Safar atau bersafar adalah pergi tahlil beramai-ramai ke tempat keramat untuk menjauhkan diri dari bahaya pada bulan Safar. ${ }^{7}$ Sedang yang dimaksud di sini adalah bulan Safar sebagai nama bulan kedua setelah bulan Muharram dalam Kalender Hijriah.

Kata tradisi berasal dari Bahasa Latin tradition yang berarti diteruskan atau kebiasaan. Dalam pengertian yang paling sederhana, tradisi adalah sesuatu yang telah dilakukan sejak lama dan menjadi bagian dari kehidupan suatu kelompok masyarakat, biasanya dari suatu negara, kebudayaan, waktu, atau agama yang sama. Hal yang mendasar dari tradisi adalah informasi yang diteruskan dari generasi baik tertulis maupun (sering kali) lisan, karena tanpa adanya informasi yang diteruskan tersebut maka suatu tradisi akan sudah dipastikan akan punah.

Jadi yang dimaksud dalam penelitian ini adalah keyakinan yang merupakan rasa keagamaan dalam diri sebagian masyarakat Banjar terhadap bulan Safar yang diyakini dapat membawa kesialan. Oleh karena itu masyarakat

\footnotetext{
${ }^{6}$ Departemen Pendidikan dan Kebudayaan RI, Kamus BesarBbahasa Indonesia, Jakarta: Balai Pustaka, 1993), edisi II, h. 753.

${ }^{7}$ Ibid., h. 285
} 
harus berhati-hati dalam segala hal, melakukan kebiasaan pada bulan Safar tertentu dengan motivasi dan tujuan tertentu secara psikologis.

\section{Metode Penelitian}

Pada dasarnya penelitian ini adalah penelitian lapangan (field research), di mana sejumlah data diperoleh dari sebagian masyarakat Kota Banjarmasin, Kabupaten Banjar, Kabupaten Hulu Sungai Selatan dan Hulu Sungai Utara.

Jenis data yang diperlukan dalam penelitian ini adalah terdiri dari data primer/pokok dan data skunder/pelengkap. Data primer/pokok meliputi datadata yang berhubungan dengan kepercayaan sebagian masyarakat Banjar terhadap bulan Safar disertai tradisi yang mereka lakukan pada bulan Safar, kemudian faktor-faktor yang menyebabkan kepercayaan dan tradisi itu bertahan serta motivasi dan tujuannya. Sedang data sekunder adalah data pendukung/pelengkap yang ada hubungannya dengan permasalahan yang diteliti.

Teknik pengumpulan data dilakukan dengan observasi/pengamatan secara langsung di lapangan mengenai tradisi atau aktivitas sebagian masyarakat pada bulan Safar. Interviu/wawancara yang dilakukan penulis dengan cara melakukan pertanyaan langsung kepada responden untuk menggali data tentang kepercayaan sebagian masyarakat Banjar terhadap bulan Safar, faktor psikologis apa yang mendasari kepercayaan dan tradisi itu dan apa motivasi serta tujuan mereka melakukan tradisi atau aktivitas pada bulan Safar. Dokumenter dengan cara mengumpulkan catatan, arsip dan literatur yang ada kaitannya dengan masalah yang diteliti.

Setelah data diolah dilanjutkan dengan analisis secara diskripsi kualitatif dengan menggunakan pendekatan teologis terhadap kepercayaan sebagian masyarakat terhadap bulan Safar dan tradisi yang dilakukan pada bulan Safar. Sedang pendekatan psikologis (Psikologi Islam) untuk menganalisis faktorfaktor psikologis apa yang mendasari kepercayaan dan tradisi/aktivitas tersebut beserta motivasi dan tujuannya. Selanjutnya penulis membuat beberapa simpulan sesuai dengan perumusan masalah. Dan terakhir dibuat laporan akhir, penggandaan dan penjilidan sesuai ketentuan yang berlaku

\section{Temuan Lapangan}




\section{Kepercayaan dan Tradisi Perilaku Masyarakat pada Bulan Safar}

Secara umum masyarakat Banjar mempercayai bulan Safar adalah bulan panas atau bulan sial atau yang disebut dengan syahrul har. Bulan Safar mereka anggap sebagai bulan pelatihan awal untuk pengendalian emosi. Pernyataan ini diperoleh dari para rerponden di Desa Kuin Utara Kota Banjarmasin, Desa Bincau Martapura Kabupaten Banjar, Desa Sungai Raya Kandangan Kabupaten Hulu Sungai Selatan dan Desa Haur Gading Amuntai Kabupaten Hulu Sungai Utara.

Kepercayaan terhadap bulan Safar mayoritas mereka anggap sebagai ajaran agama, hanya sebagian kecil yang menganggap pendapat ulama terdahulu/tradisi orang tua dahulu. Hal ini beralasan karena mereka mengetahuinya dari tokoh agama/guru agama di kampung yang menyampaikan pada saat pengajian. Menurut seorang responden dari Hulu Sungai Utara, kepercayaan terhadap bulan Safar terdapat dalam kitab-kitab Ulama dahulu seperti Kitab "Kin₹u al-Najah wa al-Surur" dan Kitab "Nihayah al_Zin" yang mengatakan bahwa bulan Safar adalah bulan diturunkannya bala yang akan dibagikan sepanjang tahun. Bagi sebagian masyarakat sendiri memang ada yang pernah mengalami kesialan di bulan Safar.

Untuk menghindari kesialan di bulan Safar dianjurkan untuk mengingat Allah dan banyak beristigfar, dilarang bepergian jauh kecuali ada keperluan yang mendesak, utamanya pada hari arba mustamir yaitu hari Rabu terakhir bulan Safar yang menjadi hari diturunkannya bala musibah untuk setahun.

Beberapa perilaku masyarakat pada bulan Safar adalah:

a. Melakukan upacara tolak bala pada hari Arba Mustamir

Di Desa Kuin, seorang tokoh agama memimpin berbagai amaliah tolak bala dengan salat sunat dan membaca Yasin, pada pertengahan ayat 58, "Salamun qaula min Rabbi al-Rabim" dibaca 313 kali dan diakhiri dengan doa. Acara ini diikuti sekitar 600 jamaah pengajiannya. Selain itu ada pula masyarakat yang melaksanakan di rumah masing-masing dipimpin oleh kepala keluarga.

Di Martapura, sebagian masyarakat melaksanakana selamatan tolak bala dengan membaca Surah Yasin bersama di surau musalla atau di rumah pemimpin upacara dengan niat agar dihindarkan dari mara bahaya. Tidak ada peralatan khusus, hanya air minum yang diletakkan dihadapan pemimpin upacara, Air itu diminum agar mendapat berkah dari Allah. Ada juga yang melakukan ritual khusus pada hari itu berupa mandi dan salat sunnat serta 
membaca Surah Yasin serta memasukkan azimat ke dalam air dan diminum dengan harapan kita terlepas dari bala dan musibah pada hari itu serta sepanjang tahun. Ritual itu bisa dilaksankan sendiri bisa pula dilaksanakan bersama-sama di surau setempat yang biasanya dipimpin oleh tokoh masyarakat/guru agama dan dikuti masyarakat sekitar, kadang dengan menghidangkan kue surabi dengan mengambil i tibar bahwa kue surabi tersebut sebagai tameng bagi kesialan di bulan safar.

Di Hulu Sungai Selatan, selamatan tolak bala pada hari arba mustamir dengan salat sunat berjamaah, membaca Surah Yasin dan doa, terdapat hidangan khusus dari berbagai jenis ketupat, yaitu ketupat bala, burung, balu, tungkul, keminting, bawang, banjar, dada ayam balangsai, dll. Juga minum air/banyu rajahan pada piring dari orang alim yang direndam dalam baskom besar, dipimpin seorang tokoh.

Di Hulu Sungai Utara, ada tradisi tolak bala yang dilaksanakan pada hari arba mustamir yang dilakukan oleh anak-anak kecil, misalnya anak-anak SD atau madrasah ibtidaiyyah. Anak-anak tersebutlah yang kemudian melakukan arakarakan keliling kampung, dengan dipimpin oleh gurunya sendiri. Mereka membawa bekal makanan, dan setelah selesai melakukan arak-arakan tersebut, mereka kemudian makan bersama. Kegiatan ini rutin dilakukan jika sudah berada pada bulan Safar, tepatnya pada saat arba mustamir. Menurut beliau kenapa anak-anak yang melaksanakan, karena anak-anak tersebut tidak berdosa, sehingga Allah tidak akan mau menurunkan bala-Nya kepada mereka, karena permohonan atau tolak bala yang dilakukan anak-anak yang tidak berdosa tadi. Selain itu ada kehati-hatian berujud larangan untuk mengambil air di sungai pada saat hari arba mustamir. Kolam-kolam air di rumah hendaknya dipenuhi terlebih dahulu sebelum tiba arba mustamir. Diyakini pada saat arba mustamir itu, kata orang terdahulu, setan-setan atau iblis mandi di sungai pada hari tersebut maka bisa saja bala akan diturunkan melalui sungai itu.

b. Batimbang anak di bulan Safar

Di beberapa tempat di Kalimantan Selatan, sebagian keluarga yang dikaruniai anak lahir pada bulan Safar, mengadakan upacara batimbang anak setelah genap 1 tahun. Hasil timbangan atau berat badan anak akan dipadankan dengan nasi ketan (lakatan) atau dodol (khusus di Kandangan). Dengan ritual ini diharapkan anak terbebas dari pengaruh buruk bulan Safar dan berperilaku manis dan indah seperti lakatan yang lamak dan manis, hidupnya penuh berkah dan bermanfaat bagi orang lain, berperilaku terpuji dan terhindar dari penyakit. 
Upacara batimbang anak bisa saja dilakukan pada saat acara tasmiyahan, yang dipimpin oleh orang alim, atau bisa juga oleh bidan yang membantu persalinan si ibu yang melahirkan tersebut. Anak tersebut dimasukkan ke dalam sebuah ayunan, kemudian ayunan yang satunya lagi di masukkan lakatan, jadi posisinya seperti sebuah timbangan. Upacara ini dilakukan selain karena alasanalasan di atas juga untuk menghindarkan anak dari keterkaitannya dengan "orang sebelab". Jadi kalau tidak dilakukan upacara tersebut, dikhawatirkan anak tersebut akan sakit-sakitan, karena diganggu makhluk dari "alam sebelab".

Acara batimbang anak biasanya dilanjutkan dengan acara selamatan sekaligus ceramah (belajaran) dengan pembacaan ayat-ayat suci Alquran dengan harapan supaya anak kelak dapat tenang dan tidak bersifat pemarah (pamanasan). Acara batimbang anak ini biasanya dipimpin oleh sepuh kampung atau tuan guru. Menurut pemahaman masyarakat Banjar, anak yang lahir pada bulan safar mempunyai sifat pemarah dan egois.

Tradisi batimbang di bulan Safar masih dilakukan sebagian masyarakat pada makam-makam tua seperti pada makam Pangeran Suriansyah di Kuin dengan membacakan Surah Yasin serta ditutup dengan Fatibah 4 (Surah alFatibah Surah al-Ikblas, Surah al-Falaq, dan Surah al-Nas), dilanjutkan dengan do'a tolak bala dan do'a selamat dan dipimpin oleh penjaga-penjaga makam. Perlengkapan yang biasa digunakan pada acara batimbang di makam tua ini lebih beragam seperti kue cucur, apam, cincin, tapai, lakatan, dan lain-lain.

Adat batimbang ini sudah mulai luntur seiring perkembangan zaman yang semakin modern. Keyakinan masyarakat bahwa anak itu tidak tergantung pada bulan apa dia dilahirkan, tetapi tergantung pendidikan dari orang tua sendiri.

c. Tidak melaksanakan perkawinan

Kepercayaan terhadap kesialan bulan Safar juga terwujud dalam larangan mengadakan perkawinan sama pada ke empat deerah penelitian. Menurut kepercayaan, hal tersebut memang ada hitung-hitungannya. Beberapa ketakutan melaksanakan perkawinan pada bulan Safar adalah dikhawatirkan perkawinannya tidak berjalan mulus, kemungkinan pernikahan tersebut tidak langgeng, akan sering terjadi percekcokan, salah satu meninggal dunia, bahkan terjadi perceraian. Hal tersebut diyakini karena pada bulan tersebut Allah menurunkan bala. Bagi responden, bulan yang baik untuk perkawinan adalah bulan Rabiul Awal/bulan Mulud dan bulan Syawal. 


\section{d. Tidak mendirikan rumah}

Semua responden menyatakan bahwa membangun rumah di bulan Safar dianggap bagus yang berakibat rumah akan terasa dingin dan sejuk dan penghuninya merasa nyaman dan tenteram menempatinya.

e. Tidak memulai usaha dagang

Menurut para responden (walaupun mereka bukan pedagang), sebaiknya tidak memulai usaha dagang pada bulan Safar karena dapat berakibat kerugian. Tradisi ini mereka ketahui dari orang-orang tua mereka dahulu.

f. Berhati-hati dalam berbicara

Dalam pergaulan hendaklah brhati-hati di dalam berbicara, karena bulan Safar dianggap bulan panas dan sial, maka salah bicara bisa menjadi fatal dan dapat berakibat perselisihan.

g. Berhati berbelanja makanan/minuman di warung

Ada kepercayaan masyarakat di daerah Kabupaten Banjar, Hulu Sungai Selatan dan Hulu Sungai Utara bahwa pada bulan Safar orang harus berhatihati membeli makanan terutama yang terbungkus/tertutup karena ada orang yang melepas racun sekali dalam setahun yang mencari tumbal dari kajian/ilmu hitamnya. Racun itu dapat masuk ke dalam makanan/minuman yang bila termakan/terminum dapat mengakibatkan sakit (biasanya muntah darah setelah menyantap makanan atau minuman tersebut, sakit ini tidak bisa diobati secara medis kecuali berobat ke Paranormal, lebih parahnya lagi dapat mengakibatkan kematian. Dalam istilah orang Banjar disebut terkena rampian (sejenis racun yang dilepaskan di bulan Safar).

h. Berhati-hati menyalakan api

Dalam bulan Safar memang disuruh berhati-hati dalam segala hal termasuk dalam menyalakan api. Tapi ada pula yang menganggap bahwa menyalakan api memang harus berhati-hati walaupun tidak di bulan Safar.

\section{Faktor-Faktor yang Mendasari Kepercayaan dan Tradisi di Bulan Safar}

Sebagian besar responden meyakini bahwa kepercayaan dan tradisi yang mereka lakukan berdasarkan pendapat ulama zaman dahulu dengan merujuk kitab-kitab klasik. Penjelasan mengenai bulan Safar serta amaliah-amaliah apa saja yang harus dilakukan di bulan Safar ini mereka dapatkan dari pengajian yang diisi oleh ulama-ulama yang dianggap masyarakat sebagai panutan. 
Selain itu, kepercayaan terhadap bulan Safar sebagai bulan sial dan amaliah yang dilakukan merupakan tradisi dan adat yang diwariskan secara turun temurun dari oraang-orang tua mereka. Berdasarkan pengalaman orangorang tua mereka, kalau mengerjakan apa yang biasa dilakukan pada bulan Safar, maka insya Allah akan selamat dan terhindar dari musibah. Sebaliknya kalau tidak mengerjakannya dikhawatirkan akan terkena musibah. radisi itu semata-mata dilakukan untuk berhati-hati saja.

\section{Motivasi dan Tujuan Masyarakat MelaksanakanTradisi Bulan Safar}

Ritual-ritual yang dilakukan pada bulan Safar selain untuk menangkal bala musibah yang turun tetapi lebih jauh ia merupakan sebuah usaha untuk meminta pertolongan dan upaya pendekatan serta penyerahan diri kepada Tuhan yang maha kuasa dengan harapan kita akan hidup selamat dan bahagia tidak hanya dibulan Safar tersebut tetapi di sepanjang tahun dan atau sepanjang hidup.

Sebagian responden berpendapat bahwa kepercayaan ini bukanlah ajaran agama melainkan hanyalah adat dan tradisi saja, karena hal tersebut tidak dibahas di dalam Alquran dan Hadis, namun sebagian mereka berpendapat bahwa mengerjakan tradisi-tradisi di atas adalah upaya mereka untuk menyesuaikan diri serta diterima oleh lingkungan sekitarnya.

\section{Analisis}

Kalau kita perhatikan kepercayaan masyarakat terhadap bulan Safar sebagai bulan yang membawa kesialan dapat dipahami dari asal kata Shafar (صفر) yang diindonesiakan Safar, Safar adalah nama bulan kedua sesudah bulan Mubarram pada kalender Hijriyah. Sedangkan jika ditinjau dari segi bahasa, Safar terkait dengan beberapa pengertian, yaitu 1). Safar (صفر) berarti penyakit kuning; lapar; cacing perut; bulan kedua sesudah Muharram. 2). Sifr (صفر) berarti kosong, nol. 3). Sufr (صفر) berarti kuning. ${ }^{8}$

Bulan ini dinamai dengan 'Safar', terkait dengan beberapa pengertian tersebut, di mana orang-orang Arab pada masa Jahiliyah dahulu berangkat mengembara. Mereka meninggalkan kediaman mereka pada bulan tersebut sehingga rumah-rumah tinggal menjadi kosong (صفر); dan pada suatu waktu pernah mereka berangkat bertepatan musim panas dan kering, pada saat daun-

\footnotetext{
${ }^{8}$ Husein Nafarin, Makalab Bulan Safar, Tinjanan Historis dan Beberapa Pemikiran Terbadapnya, (Banjarmasin, 2001), h. 1
} 
daun manjadi kekuning-kuningan (صفر); dan banyaklah penderitaan dan petaka yang dialami oleh mereka (صفر).?

Bila kita telusuri lebih jauh ternyata kepercayaan akan adanya kesialan di bulan Safar sudah ada sejak dahulu di kalangan bangsa Arab. Disebutkan bahwa pada hari Rabu terakhir (arba mustamir) di bulan Safar pada setiap tahunnya turun tiga ratus dua puluh ribu (320.000) bala. Hari itu adalah hari yang paling sulit dalam setahun, Bala-bala ini kemudian disebarkan dalam harihari selama setahun itu. Penjelasan demikian dapat kita temukan antara lain di dalam kitab:

1. Syekh Abd al-Hamid Muhammad al-Quds, seorang mudarris (pengajar dan Imam di Masjid Al Haram Makkah (1280 - 1334 H); Kitab "Kanz al-Najah wa al-Surur fi al-Ad'iyah allati Tasyrah al-Shudur".

2. Selebaran tuan Guru Haji Jamhuri yang menyebutkan diambil dari Kitab "Fath al-Malik al Majid" oleh al-Dairubi.

3. M. Qusairi Hamzah, "Risalah Amaliab” yang beliau kutip dari Kitab Fawa'id al-Ukhrawiyah.

Sebagian bangsa Arab mengundurkan bulan Mubarram ke bulan Safar sehingga mereka berperang di bulan Muharram; dan menjadikan bulan Safar sebagai bulan Mubarram. Di antara mereka ada yang beranggapan bahwa Safar (dibaca: صفر) adalah sejenis ular maksudnya cacing (حية في البطن) didalam perut yang menggigit manusia jika ia lapar, sehingga perut terasa perih dan nyeri karena gigitannya. Hal ini diartikan bahwa mereka merasa pesimis (tasya'um) dengan datangnya bulan Safar karena akan terjadi banyak bencana dan kegalauan. ${ }^{10}$

Adnani Iskandar seperti dikutip oleh Husein Nafarin pernah menjelaskan bahwa dalam tarikh pernah diriwayatkan bahwa hancurnya bendungan Ma'rib di Yaman terjadi pada bulan Safar. Diriwayatkan pula bahwa sesudah perang Sa'iba, seorang wanita Yahudi memberikan paha kambing masak beracun kepada Nabi saw. dengan maksud membunuhnya. Tetapi beliau selamat, namun seorang sahabat bernama Barra bin Azib tewas. Ini terjadi pada bulan Safar. ${ }^{11}$

\footnotetext{
${ }^{9}$ Ibid

${ }^{10}$ Syekh Abdul Hamid Muhammad al-Quds, Kanz al-Najah wa al-Surur fi al-Ad'iyah Allati Tasyrah al-Shudur, (1998 M/1419 H.) h. 35. Lihat juga Ibnu Manzhur, Lisan Al Arab, (Teheran Iran, Nasyr Adab al-Huzah, 1405 H.), jilid 4. h. 463.

${ }^{11}$ Husein Nafarin, op. cit., h. 4.
} 
Kepercayaan terhadap kesialan bulan Safar yang merebak di sebagian masyarakat tidak saja di Kalimantan Selatan dan Indonesia, tetapi sudah ada pada masa Arab Jahiliyah dahulu yang tidak diketahui secara pasti sejak kapan adanya. Namun pengetahuan tentang kesialan bulan Safar dan cara menangkal bala yang diturunkan berdasarkan kitab-kitab di atas.

Kepercayaan terhadap bulan Safar sebagai bulan sial bukan merupakan ajaran Islam. Maka terhadap ketentuan Allah, seorang muslim wajib beriman kepada Qadla dan Qadar Allah. Amin al-Kurdi menegaskan bahwa qadha adalah keputusan Allah terhadap sesuatu rencana yang telah ditentukan. ${ }^{12}$ Hal senada dikemukakan oleh Al-Ghazali bahwa qadha adalah ketentuan-ketentuan yang diciptakan Tuhan di alam 'azali secara garis besarnya. ${ }^{13}$ Sedangkan qadar menurut Al-Ghazali adalah terjadinya sesuatu dalam kenyataan secara terperinci pada waktu tertentu sesuai ketentuan Allah yang sudah ditetapkanNya pada azali. ${ }^{14}$ Hal ini diperkuat dengan penjelasannya dalam Ibya Ulum alDin, bahwa yang dimaksud qadar adalah pelaksanaan qadha yang telah ditetapkan Allah sebelumnya. ${ }^{15}$ Beriman kepada takdir Allah berarti meyakini bahwa segala yang baik dan buruk merupakan takdir Allah yang tidak terkait dengan bulan Safar.

Seiring dengan perkembangan zaman, kepercayaan sebagian masyarakat Banjar terhadap hal-hal yang dijelaskan diatas, memang sudah mulai berkurang dan mengalami perubahan. Namun tentu saja, masih ada beberapa orang yang menganggap Safar sebagai bulan kesialan, penuh bencana, penyakit, panas, dilarang melangsungkan pesta pernikahan atau sunatan, dan nahas.

Pengetahuan tentang segala yang gaib dan segala yang akan terjadi hanya ada pada Allah swt. Apa yang akan terjadi dan menimpa seseorang manusia pada waktu akan datang, tidak ada yang mengetahui kecuali Allah swt, karena Dialah yang menghendaki dan menentukan-Nya. Oleh karena itulah, maka manusia diperintah berusaha dan berikhtiar semampu mungkin, sambil berdo’a dan bertawakkal agar mendapatkan yang terbaik.

Adapun faktor bertahannya kepercayaan dan tradisi sebagian masyarakat terhadap bulan Safar adalah:

1. Sugesti

${ }^{12}$ Muhammad Amin al-Kurdi, Tanwir al-Qulub fi Mu'amalat al-A'lam al-Ghuyub, Singapura: al-Haramayn, t.th, h. 87.

${ }^{13}$ Abu Hamid al-Ghazali, Arba'in fi Usbul al-Din, Maktabah Junaidy, 1918, h.6.

${ }^{14} \mathrm{Ibid}$, h. 6.

${ }^{15}$ Abu Hamid al-Ghazali, Ibya 'Ulum al-Din, Vo.I. (Cairo: Dar al-Sya'b, t.th), h.156. 
Proses sugesti terjadi karena kepercayaan terhadap kesialan bulan Safar dan amaliah yang dilakukan disampaikan oleh tokoh agama yang oleh sebagian masyarakat diyakini sebagai bagian ajaran Islam, karenanya masyarakat menjadi sugestibel/terpengaruh untuk mempercayai dan melakukan amliah dimaksud. Terutama untuk mendapatkan keselamatan dan menhindari kesialan.

2. Peniruan perilaku (modelling).

Menurut Bandura, kebanyakan belajar terjadi tanpa reinforcemen yang nyata. Dalam penelitiannya, ternyata orang dapat mempelajari respon baru dengan melihat respon orang lain, bahkan belajar tetap terjadi tanpa ikut melakukan hal yang dipelajari itu, dan model yang diamatinya juga tidak mendapat renforsemen dari tingkah lakunya. Belajar melalui observasi jauh lebih efisien dibanding belajar melalui pengalaman langsung. Melalui observasi orang dapat memperoleh respon yang tidak terhingga banyaknya, yang mungkin diikuti dengan hubungan dan penguatan. ${ }^{16}$ Dari wawancara yang telah dilakukan membuktikan bahwa hanya sebagian kecil saja dari para responden yang mengetahui atau mendapatkan langsung dalil/bukti bahwa ritual/tradisi pada bulan Safar memang berasal dari ajaran agama Islam atau bukan. Sebagian besar dari mereka hanya melakukan peniruan perilaku (modelling) dari orangorang sekitar dan orang-orang terdahulu. Modelling bukan sekedar menirukan atau mengulangi apa yang dilakukan orang model (orang lain), tetapi modeling melibatkan penambahan dan atau pengurangan tingkah laku yang teramati, menggeneralisir berbagai pengamatan sekaligus, melibatkan proses kognitif. Adapun tahap-tahapnya sebagai berikut:

a. Perhatian

Sebagian masyarakat Banjar akan mengamati pelaksanaan ritual-ritual keagamaan yang dilaksanakan pada bulan Safar

b. Retensi

Ritual yang telah diamati kemudian disimpan dalam ingatan dan akan bisa ditirukan lagi ketika pelaksana ritual tersebut tidak ada lagi.

c. Reproduksi motoris

${ }^{16}$ Matt Jarvis, Teori-teori Psikologi: Pendekatan modern untuk memahami perilaku, perasaan \& Pikiran Manusia. (Bandung: Nusa Media, 2011), h. 29 
Data yang telah disimpan dalam ingatan tadi akan kembali bisa dipanggil dan dilaksanakan apabila dibutuhkan. Untuk dapat menirukan pelaksanaan ritual dengan baik maka seseorang harus memiliki kemampuan motoris.

d. Insentif dan motivasi

Orang yang melaksanakan ritual di bulan Safar harus melihat bahwa ritual tersebut sebagai ritual yang benar dan bermanfaat sehingga orang tersebut termotivasi untuk melaksanakannya.

Manusia berbuat pasti karena adanya motivasi dan tujuan. Dalam kamus bahasa Indonesia mendefinisikan motif sebagai sebab-sebab yang menjadi dorongan; tindakan seseorang. ${ }^{17}$ Secara umum motivasi adalah dorongan dan kekuatan yang mengarahkan manusia berperilaku. Dalam kamus bahasa Indonesia, motif sebagai sebab-sebab yang menjadi dorongan; tindakan seseorang. ${ }^{18}$ Menurut Riggio, motivasi adalah "force that energizes, direct, and sustains behavior." 19 Motivasi merupakan keadaan dalam diri seseorang yang mendorong perilaku ke arah tujuan. ${ }^{20}$ Motivasi menurut Alex adalah yang melatarbelakangi perilaku, yang dikenal juga sebagai suatu desakan atau keinginan atau kebutuhan atau suatu dorongan. ${ }^{21}$

Motivasi dapat dibedakan menjadi dua, yaitu motivasi intrinsik dan motivasi ekstrinsik. Motivasi intrinsik adalah motivasi yang berasal dari dalam diri seseorang; seseorang ingin melakukan sesuatu karena ingin melakukannya, sedangkan motivasi ekstrinsik berasal dari luar diri seseorang. ${ }^{22}$

Bagi masyarakat Banjar, kepercayaan atau keyakinan tentang pelaksanaan ritual serta mitos pada bulan Safar ini boleh jadi dimotivasi keinginan untuk mencari keselamatan dan menghindari kesialan, karena memang banyak kasus atau kejadian yang menimpa orang Banjar dan kebetulan terjadinya di bulan Safar. Sehingga karena seringnya terjadi apa yang ditakuti oleh orang Banjar di atas pada bulan Safar, lalu mereka menjustifikasi bulan Safar sebagai bulan penuh kesialan, marabahaya, dan seterusnya. Akibatnya, dalam perspektif orang

${ }^{17}$ Poewadarminto, Kamus Bahasa Indonesia. (Jakarta: Pusat Pembinaan dan Pengembangan Bahasa Dep. Pendidikan dan Kebudayaan, 1976), h. 76.

${ }^{18}$ Ibid., h. 76.

${ }^{19}$ Riggio, R.E., Introduction To Industrial Organozational Psychology. (Scott Foresmen/Little Brown Higher Education, 1990), h. 653

${ }^{20}$ Bimo Walgito, Pengantar Psikologi Umum. (Yogyakarta: Penerbit Andi, 2009), h. 222

${ }^{21}$ Alex Sobur, Psikologi Umum dalam Lintasan Sejarah. (Bandung: Pustaka Setia, 2003, h. 266

${ }^{22}$ Lynn Wilcox, ibid. h. 137 
Banjar, bulan Safar adalah bulan yang harus diwaspadai dan ditakuti. Pantang bagi mereka untuk melakukan kegiatan-kegiatan penting di bulan Safar, misalnya perkawinan, membangun batajak (rumah), menurunkan kapal, bepergian jauh (madam), memulai usaha (dagang, bercocok tanam), mendulang emas atau intan, dan sebagainya. Sebab, ujung dari semua kegiatan tersebut dalam pemahaman mereka adalah kegagalan dan kesusahan, dan khusus bagi mereka yang mendulang sangat rentan terkena racun atau wisa.

\section{Penutup}

Berdasarkan hasil temuan dalam penelitian ini, maka dapat disimpulkan bahwa:

Masyarakat Banjar meyakini bahwa bulan Safar adalah bulan panas atau bulan sial atau yang disebut dengan syahrul har. Keyakinan tersebut diperkuat berdasarkan riwayat Ulama dahulu yang mengatakan bahwa bulan Safar adalah bulan diturunkannya kesialan yang akan dibagikan sepanjang tahun karena itu kita dianjurkan untuk mengingat Allah dan banyak beristigfar didalamnya, dan dilarang untuk bepergian jauh kecuali ada keperluan yang sangat mendesak, utamanya pada hari arba mustamir yaitu hari Rabu terakhir bulan safar yang menjadi hari diturunkannya bala musibah dalam setahun.

Kepercayaan dan tradisi yang dilakukan oleh sebagian masyarakat Banjar diyakini berdasarkan pendapat orang-orang alim atau ulama zaman dulu dengan merujuk kitab-kitab klasik. Hal itu menandakan bahwa tradisi atau ritual di bulan safar serta pendapat yang mengatakan bahwa bulan Safar adalah bulan bala atau bulan sial mempunyai dalil yang kuat dan disebutkan dalam ajaran agama, atau dalam arti bukan tradisi belaka. Penjelasan mengenai bulan Safar serta amaliyah-amaliyah apa saja yang harus dilakukan di bulan Safar ini mereka dapatkan dari pengajian yang diisi oleh ulama-ulama yang dianggap masyarakat sebagai panutan.

Amaliah/tradisi yang dilakukan di bulan Safar adalah a. Melakukan upacara tolak bala pada hari Arba Mustamir b. Batimbang anak di bulan Safar, c. Tidak melaksanakan perkawinan, d. Tidak mendirikan rumah, e.Tidak memulai usaha dagang, f. Berhati-hati dalam berbicara, g. Berhati berbelanja makanan/ minuman di warung, h. Berhati-hati menyalakan api

Adapun faktor bertahannya kepercayaan dan tradisi sebagian masyarakat terhadap bulan Safar adalah faktor sugesti dan peniruan perilaku (modelling), karena kepercayaan terhadap kesialan bulan Safar dan amaliah yang dilakukan disampaikan oleh tokoh agama yang oleh sebagian masyarakat diyakini sebagai 
bagian ajaran Islam, karenanya masyarakat menjadi sugestibel/terpengaruh untuk mempercayai dan melakukan amliah dimaksud. Terutama untuk mendapatkan keselamatan dan menhindari kesialan.

Adapun motivasi dan tujuan sebagian masyarakat Banjar mempercai bulan Safar sebagai bulan sial dan melakukan amaliah di bulan itu adalah keinginan untuk mencari keselamatan dan menghindari kesialan.

\section{Daftar Pustaka}

Abdullah, Amin, (1989). Agama dan Akal Pikiran, Jakarta: Rajawali.

Daud, Alfani, (1997), Islam dan Masyarakat Banjar, Diskripsi dan Analisi Kebudayaan Banjar, Jakarta, RajaGrafindo Persada.

Departemen Pendidikan dan Kebudayaan RI, (1993), Kamus Besar Babasa Indonesia, Jakarta, Balai Pustaka.

Al-Ghazali, Abu Hamd, Arba’in fi Ushul al-Din, (1918), Maktabah Junaidy. , (t.th.), Ibya 'Ulum al-Din, Vo.I. Cairo, Dar al-Sya'b.

Hamzah, M. Qusairi, (1998M/1419H), .Risalah Amaliah, Pemangkih.

Jarvis, Matt, (2011), Teori-teori Psikologi : Pendekatan modern untuk memahami perilaku, perasaan \& Pikiran Manusia. Bandung, Nusa Media.

Kusumah, Hilman Hadi, (1993), Antropologi Agama, Bandung: Citra Aditya Bakti.

Koentjaraningrat, Sejarah Antropologi I, Jakarta, Aksara Baru, 1982.

Manzhur, Ibnu, (1405 H), Lisan Al Arab, Teheran Iran, Nasyr Adab al Huzah, jilid 4.

Muhammad Amin al-Kurdi, (t.th.), Tanwir al-Qulub fi Mu'amalat al-A'lam alGhuyub, Singapura: al-Haramayn.

Nafarin, Husein, (2001), Makalah Bulan Safar, Tinjanan Historis dan Beberapa Pemikiran Terhadapnya, Banjarmasin.

Uriansyah, et. all.(editor), (2000), Urang Banjar dan Kebudayaannya, Banjarmasin, Badan Penelitian dan Pengembangan Daerah propinsi Kalimantan Selatan. 
Poewadarminto, (1976), Kamus Bahasa Indonesia. Jakarta, Pusat Pembinaan dan Pengembangan Bahasa Dep. Pendidikan dan Kebudayaan.

Sobur, Alex, (2003), Psikologi Umum dalam Lintasan Sejarah. Bandung, Pustaka Setia..

Riggio, R.E., (1990)., Introduction To Industrial Organozational Psychology Scott Foresmen/Little Brown Higher Education

Al-Quds, Syekh Abdul Hamid Muhammad, (1998 M/1419 H), Kan₹ al-Najah wa al-Surur fi al-Ad'iyah Allati Tasyrah al-Shudur.

Walgito, Bimo, , (2009), Pengantar Psikologi Umum. Yogyakarta, Penerbit Andi. 